\title{
УПРАВЛЕНЧЕСКОЕ ПРАВО
}

Г.И. Калинин

\section{ПОЛНОМОЧИЯ ПО КОНТРОЛЮ И НАДЗОРУ ЗА КАЧЕСТВОМ И БЕЗОПАСНОСТЬЮ ПИЩЕВЫХ ПРОДУКТОВ ЖИВОТНОГО ПРОИСХОЖДЕНИЯ}

B соответствии с п. 1 ст. 13 Федеральный закон от 2 января 2000 г. № 29-Ф3 «О качестве и безопасности пищевых продуктов» (с изменениями от 19 июля 2011 г.) $)^{1}$ государственный надзор в области обеспечения качества и безопасности пищевых продуктов, материалов и изделий осуществляется федеральными органами исполнительной власти, органами исполнительной власти субъектов РФ, уполномоченными на осуществление соответственно федерального государственного санитарно-эпидемиологического надзора, федерального государственного ветеринарного надзора, регионального государственного ветеринарного надзора, согласно их компетенции в порядке, установленном Правительством РФ.

Вместе с тем, в вопросе разграничения полномочий по государственному надзору в области обеспечения качества и безопасности пищевых продуктов животного происхождения имеется серьёзная проблема, заслуживающая внимания и требующая рассмотрения. Она имеет исторические корни.

Руководитель Россельхознадзора С.А. Данкверт в одном из своих интервью подчеркнул, что «возможно, мы жили не так ярко, как на капиталистическом Западе, но натуральность и безопасность продуктов, которые покупали к столу граждане Советского Союза, государство им гарантировало» ${ }^{2}$. Д.Н. Лыжин отмечает, что уровень обеспечения безопасности пищевых продуктов, несмотря на то, что и контролёры и контролируемые принадлежали к государственным структурам, был очень высок. Безопасностью пищевых продуктов в СССР в общем занималась санитар-

\footnotetext{
1 См.: С3 РФ. - 2000, - №2. - Ст. 150.

2 См.: Данкверт С.А. Здоровье нации - залог будущего страны. 2011. Май // Сайт Издательского дома VIP-МедиаГрупп.: http://vipvkurske.com/articles/200/.
}

но-эпидемиологическая служба, однако всё, что касалось пищевых продуктов животного происхождения было отнесено к ведению прежде всего государственной ветеринарной службы, которая осуществляла этот надзор как самостоятельно, так и совместно с медиками ${ }^{3}$.

Однако в 90-е гг. ситуация начала меняться. В это время Госсанэпиднадзор отменяет некоторые санитарные правила для предприятий — изготовителей и переработчиков пищевого сырья и продуктов и принимает новые, которые либо сильно сужали и принижали полномочия государственного ветеринарного надзора в этой области (например - в области переработки рыбы ${ }^{4}$ ), либо пытались совсем упразднить его (например, в области переработки молока ${ }^{5}$. Эти отмены и принятия производились Госсанэпиднадзором единолично, хотя в советское время данные документы принимались только совместно с Минсельхозом СССР и Главветупром.

См.: Лыжин Д.Н. Международный опыт и перспективы системы ветеринарного контроля в России // Сайт Независимого экспертно-сертификационного центра. Хабаровск. 2011. 10 августа.: http://www.dvnekc.ru/index. php?option $=$ com_content\&view $=$ article $\&$ id $=98: 2011-10-19-00-$ 18-15\&catid=24:toall\&Itemid $=20$.

4 См.: Санитарные правила и нормы СанПиН 2.3.4.050-96 «Производство и реализация рыбной продукции». Утверждены постановлением Госкомсанэпиднадзора РФ от 11 марта 1996 г. №6 // Официальное издание Госкомсанэпидемнадзоpa РФ. - М., 1996.

5 См.: Санитарные правила и нормы СанПиН 2.3.4.551-96 «2.3.4. Предприятия пищевой и перерабатывающей промышленности (Технологические процессы. Сырье). Производство молока и молочных продуктов». Утверждены постановлением Госкомсанэпиднадзора РФ от 4 октября 1996 г. №23 / СПС Гарант Эксперт 2010 (документ не опубликован). 
Следует рассмотреть подробно полномочия по надзору в этой сфере, поскольку как всегда возникает вопрос по разграничению полномочий с Роспотребнадзором.

Ссылаясь на Постановление Правительства РФ от 21 декабря 2000 г. № 987 «О государственном надзоре и контроле в области обеспечения качества и безопасности пищевых продуктов» ${ }^{6}$, главный госветинспектор РФ Н.А. Власов своим указанием от 15 мая

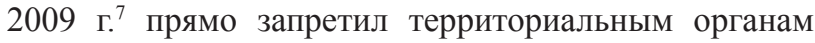
Россельхознадзора осуществлять контроль и надзор за безопасностью услуг, оказываемых в сфере розничной торговли и сфере общественного питания. Целесообразно ли это и нет ли здесь противоречия, попробуем разобраться (здесь придётся несколько затронуть полномочия Россельхознадзора).

Утверждение о поднадзорности безопасности услуг, оказываемых в сфере розничной торговли и сфере общественного питания, не Россельхознадзору, а Роспотребнадзору, формально соответствует букве действующего законодательства. Однако, речь идет именно об услугах, но не о продуктах, подлежащих ветеринарному контролю. Согласно ст. 15 Закона РФ «О ветеринарии», требования ветеринарной безопасности должны соблюдаться на всех стадиях оборота продуктов животного происхождения, в том числе и на стадии реализации. Что касается Роспотребнадзора, то при проверках предприятий розничной торговли и общественного питания специфические ветеринарные вопросы могут просто не рассматриваться. Санитарно-эпидемиологические требования к организациям торговли и обороту в них продовольственного сырья и пищевых продуктов СП 2.3.6.1066-018 (п. 8.24) и Санитарно-эпидемиологические требования к организациям общественного питания, изготовлению и оборотоспособности в них пищевых продуктов и продовольственного сырья СП 2.3.6.1079-019 (п. 7.8) регламентируют лишь наличие ветеринарных

6 См.: С3 РФ. - 2001. - № 1 (ч. II). - Ст. 123.

7 См.: Письмо Россельхознадзора от 15 мая 2009 г. №ФСHB-2/4647 // Официальный сайт Россельхознадзора: http:// www.fsvps.ru/.

8 См.: Постановление Главного государственного санитарного врача РФ от 7 сентября 2001 г. №23 «О введении в действие санитарных правил» // Бюллетень нормативных актов федеральных органов исполнительной власти. - 2001. - №41.

9 См.: Постановление Главного государственного санитарного врача РФ от 8 ноября 2001 г. №31 «О введении в действие санитарных правил» (в редакции Постановления Главного госсанврача РФ от 31 марта 2011 г. №29) / Российская газета. - 2011. - 18 мая. клейм на мясосырье а также наличие ветеринарных сопроводительных документов у продуктов животного происхождения. Некоторые специфические ветеринарные вопросы, такие как содержание и действительность ветеринарных сопроводительных документов на используемые продукты и сырье, подлежащие ветеринарному контролю, санитарные правила не рассматривают и не могут рассматривать. Поэтому сфера общественного питания и розничной торговли с точки зрения факторов опасности должна быть подконтрольна государственному ветеринарному надзору (в части качества и безопасности используемого сырья). Следует принять соответствующие нормативные акты, регламентирующие процедуру проверок, и четко разграничивающие сферу ветеринарного надзора от надзора санитарного.

В двухтысячные годы процесс урезания полномочий органов государственного надзора по контролю за предприятиями, осуществляющими переработку пищевых продуктов животного происхождения пошёл уже на более высоком уровне. Так например, Федеральный закон от 12 июня 2008 г. № 88-Ф3 «Технический регламент на молоко и молочную продукцию» отменил действие на этот продукт Федерального закона «О качестве и безопасности пищевых продуктов», практически полностью упразднил государственный ветеринарный надзор за молокоперерабатывающими предприятиями, оставив за ветеринарами только контроль за сырым молоком, сырым обезжиренным молоком, сырыми сливками. И когда Председатель Правительства РФ обвиняет Минсельхоз России в том, что «технический ваш регламент не работает» ${ }^{10}$, то это как минимум заблуждение, поскольку контроль и надзор за его выполнением осуществляет в наибольшей части Роспотребнадзор, а от первоначального проекта этого Федерального закона, внесённого Минсельхозом России, почти ничего не осталось. По сходному сценарию развивается ситуация и с переработкий других продуктов, «первая ласточка» - принятие Постановления Правительства РФ от 14 декабря 2009 г. № 1009 «О порядке совместного осуществления Министерством здравоохранения и социального развития Российской Федерации и Министерством сельского хозяйства Российской Федерации функций по нормативно-правовому регулированию в сфере контроля за качеством и безопасностью пищевых продуктов и по организации такого контроля». За органами государ-

10 См.: Савиных А. «Премьер-министр Владимир Путин - о молоке: «Ваш технический регламент не работает!». 2009 г. 9 октября // Сайт газеты «Известия».: http://www.izvestia.ru/ news $/ 354037$. 
ственного ветеринарного надзора пытаются оставить надзор только за продовольственным сырьем животного происхождения, не подвергшимся промышленной или тепловой обработке, а также пищевые продукты животного происхождения непромышленного изготовления, предназначенные для реализации на розничных рынках.

В реальности же получилось так, что Роспотребнадзор занят в основном медициной, эпидемиологией и защитой прав потребителей, проверяет в основном предприятия торговли. Органы госветнадзора «оттесняются» к животноводческим предприятиям. А перерабатывающие предприятия оказываются практически безнадзорными.

Вся эта ситуация противоречит отечественному опыту, современным реалиям и международному опыту.

В этой связи примечателен опыт Европейского Союза как одного из крупнейших производителей и экспортёров животноводческой продукции в мире. Европейский Союз декларирует, что его ветеринарное законодательство полностью отвечает принципам МЭБ. Примечательно, что из важнейших таких принципов является безусловная возможность подтвердить безопасность продуктов питания и пищевого сырья на всех стадиях производства и оборота, как говорят «от поля до вилки» ${ }^{11}$. Именно - от поля, поскольку безопасность продуктов животного происхождения начинается не только от животных, но и от безопасности кормов, пастбищ, выгулов. Сегодня членство России в ВТО, которая придерживается тех же самых принципов - уже реальность, а значит нам придётся ими руководствоваться. Не случайно все первые лица Минсельхоза России и Россельхознадзора говорят о гармонизации российского и европейского ветеринарного законодательства ${ }^{12}$. Ведь в случае с пищевыми продуктами животного происхождения только ветеринарная служба может подтвердить их безопасность по всей цепочке оборота.

В этом смысле достаточно обратить внимание на название ветеринарных органов Евросоюза, чтобы понять объём из полномочий. Так органом по нормативно-правовому регулированию в этой области является Постоянный комитет по пищевой цепи и здоровью животных (SCFCAH), Созданный во исполнение

\footnotetext{
11 См.: International Affairs. Organisations. World Organisation for Animal Health (OIE). // Сайт Европейского Союза.: http:// ec.europa.eu/food/international/organisations/oie_en.htm.

12 См.: Россельхознадзор. Гармонизация ТС/ЕС. // Официальный сайт Россельхознадзора.: http://www.fsvps.ru/fsvps/ news/harmonization.
}

Директивы Европарламента 178/2002 от 28 января 2002 г. $^{13}$ Мандат Комитета охватывает всю цепочку поставок пищи - от здоровья животных вопросы на ферме, чтобы продукт на стол потребителя - помощь ЕС эффективно иметь дело с какой-либо риск для здоровья каждом этапе производственной цепочки. Его возглавляет представитель Еврокомиссии ${ }^{14}$.

Что же касается надзорно-исполнительного органа, то его роль играет Генеральный Директорат по здравоохранению и правам потребителей (DG Health and Consumers или SANCO). Однако не следует думать что это - аналог нашего Роспотребнадзора, в полномочия этого органа входят все вопросы, хоть как либо связанные с безопасностью пищевых продуктов, например - безопасность лекарственных средств (в т.ч. для животных), карантин и защита растений ${ }^{15}$ и т.д.

Непосредственно ветеринарным органом в составе SANCO является один из его директоратов - Бюро по продовольствию и ветеринарии (Directorate $\mathrm{F}$ Food and Veterinary Office) (FVO) ${ }^{16}$, или как называют его у нас - Продовольственно-ветеринарная служба (ПВС).

Вопросы безопасности пищевых продуктов животного происхождения обеспечивают и национальные ветеринарные службы стран Евросоюза. Их названия также не оставляют сомнения в объёме полномочий. Например, в Нидерландах - Департамент ветеринарии и продовольствия Министерства сельского хозяйства, природы и качества пищевых продуктов, возглавляемый главным ветеринарным инспектором ${ }^{17}$.

13 Текст доступен на сайте: http://europa.eu.int/eurlex/pri/en/ oj/dat/2002/1_031/1_03120020201en00010024.pdf.

14 См.: EUROPA. European Commission. DG Health and Consumers. Overview // Сайт Европейского Союза.: http:// ec.europa.eu/food/committees/regulatory/index_en.htm.

15 См.: European Commission. DGs. Health and Consumers // Сайт Европейского Союза: http://ec.europa.eu/dgs/health_consumer/index_en.htm.

16 См. напр.: Evaluation of the Community Animal Health Policy (САНР) 1995-2004 and alternatives for the future (Политика оценки здоровья домашних животных на 1995-2004 гг. и альтернативы на будущее) по 2004/S 243-208899 // Сайт Европейского Союза: http://ec.europa.eu/food/animal/diseases/strategy/archives/ main_report_part1_en.pdf.

17 См. напр.: Memorandum on veterinary certification of animals and animal products to be exported from EC to Russia. Moscow. 2004. 2 september. (Меморандум о ветеринарной сертификации животных и продуктов животного происхождения для экспорта из ЕС в Россию. Москва. 2004. 2 сентября.) // Сайт Европейского Союза: http://ec.europa.eu/food/ international/trade/docs/mou_animal_02092004.pdf. 
В Латвии и Литве (кстати - очень сильная служба ещё со времен СССР, с серьёзным лабораторным оснащением, обеспечивающим интересы всего Евросоюза) продовольственно-ветеринарная служба ${ }^{18}$. В Латвии например, к объектам государственного ветеринарного надзора причислены все коммерсанты, вовлечённые в оборот продуктов животного происхождения ${ }^{19}$.

Опыт Евросоюза перенимают и другие страны. Однако весьма показательно, что передача в Украине (которая является крупным экспортёром в Россию прежде всего свинины и молочных продуктов) всех полномочий по контролю и надзору за безопасностью пищевых продуктов животного происхождения вызвала резкую критику со стороны главы Роспотребнадзора Г.М. Онищенко, что спровоцировало международный скандал ${ }^{20}$.

Примечательно, что в России главной видимой причиной ограничения полномочий Россельхознадзора в данной области является именно лобби Роспотребнадзора, довольно сильное, ведь даже ветеринарные лаборатории у нас аттестовывает Роспотребнадзор ${ }^{21}$. Между тем Россельхознадзор отозвался о передаче полномочий украинским ветеринарам как раз положительно, поскольку только ветеринары обладают всей полнотой сведений о безопасности продукта животного происхождения с момента начала его производства и оборота. Ветеринарная служба играет принципиальную роль в обеспечении интересов национальной безопасности, считают специалисты Россельхознадзора. Кроме того, нельзя забывать о том, что пищевая безопасность регулируется международным правом ${ }^{22}$.

В свете вышесказанного имеется мнение, которое является одним из тезисов настоящего исследования, что полномочия по контролю и надзору за качеством и безопасностью пищевых и иных продуктов животного происхождения на всех стадиях производства и оборота в полном объёме необходимо передать государственной ветеринарной службе. При этом европейский опыт необходимо воспринять не бездумным абсолютным копированием, а выбором самого лучшего и соединением его с положительным советским и российским опытом.

\section{Библиографический список:}

1. Данкверт С.А. Здоровье нации - залог будущего страны. 2011. Май // Сайт Издательского дома VIPМедиаГрупп.: http://vipvkurske.com/articles/200/.

2. Лыжин Д.Н. Международный опыт и перспективы системы ветеринарного контроля в России. // Сайт Независимого экспертно-сертификационного центра. Хабаровск. 2011. 10 августа.: http://www.dvnekc.ru/index. php?option=com_content\&view=article\&id=98:2011-10-19-00-18-15\&catid=24:toall\&Itemid=20.

\footnotetext{
18 См. напр.: Институт «BIOR» участвует в семинаре продовольственных и ветеринарных лабораторий стран Балтии, проходящем в Литве // Сайт Научного института пищевой безопасности, здоровья животных и окружающей среды «BIOR». Рига. Латвия.: http://www.bior.gov.lv.

19 См.: Закон Латвийской Республики «О ветеринарной медицине». Принят Сеймом 26 апреля 2001 г. Обнародован Президентом государства 16 мая 2001 г. (с изменениями по состоянию на 30 марта 2006 г.) // http://www.export.by/data/ Image/File/zaconoveterinmedicineLatvia.doc.

20 См. напр.: Онищенко раскритиковал Украину: там людей приравняли к животным // Сайт «РБК-новости». 2012 г. 8 января.: http://newsrbk.ru/news/31600/.

21 См.: Постановление Главного государственного санитарного врача РФ от 30 апреля 2003 г. № 85 “О введении в действие санитарно-эпидемиологических правил СП 1.2.1318-03 «Порядок выдачи санитарно-эпидемиологического заключения о возможности проведения работ с возбудителями инфекционных заболеваний человека I-IV групп патогенности (опасности), генно-инженерно-модифицированными микроорганизмами, ядами биологического происхождения и гельминтами» / Российская газета. - 2003. - 17 июня (специальный выпуск).
}

22 См.: Россельхознадзор ответил Онищенко за Украину / Сайт Рамблер-новости. 2012. 11 января: http://news.rambler. $\mathrm{ru} / 12403139 /$. 


\section{Управленческое право}

3. Савиных А. «Премьер-министр Владимир Путин — о молоке: «Ваш технический регламент не работает!». 2009. 9 октября // Сайт газеты «Известия».: http://www.izvestia.ru/news/354037.

\section{References (transliteration):}

1. Dankvert S.A. Zdorov'e natsii — zalog budushchego strany. 2011. May // Sayt Izdatel'skogo doma VIP-MediaGrupp.: http://vipvkurske.com/articles/200/.

2. Lyzhin D.N. Mezhdunarodnyy opyt i perspektivy sistemy veterinarnogo kontrolya v Rossii. // Sayt Nezavisimogo ekspertno-sertifikatsionnogo tsentra. Khabarovsk. 2011. 10 avgusta.: http://www.dvnekc.ru/index.php?option=com content\&view=article\&id=98:2011-10-19-00-18-15\&catid=24:toall\&Itemid=20.

3. Savinykh A. «Prem'er-ministr Vladimir Putin — o moloke: "Vash tekhnicheskiy reglament ne rabotaet!”. 2009. 9 oktyabrya // Sayt gazety «Izvestiya».: http://www.izvestia.ru/news/354037. 